
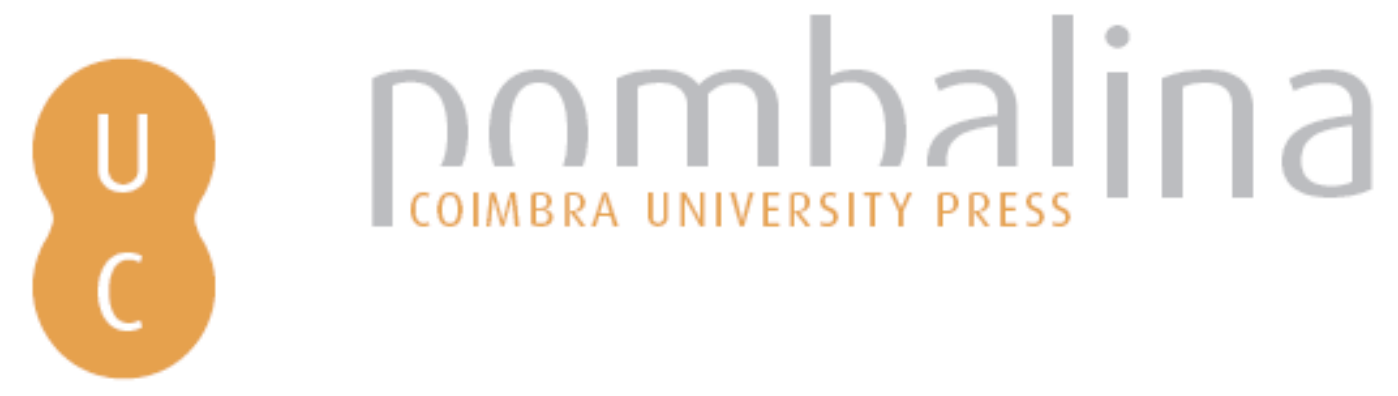

\title{
Life cycle cost optimization through an asset management based on risk principles
}

\begin{tabular}{ll} 
Autor(es): & $\begin{array}{l}\text { Santos, João; Barata, Hugo; Cordeiro, Hélio; Mendonça, Cristina; Sobral, } \\
\text { José }\end{array}$ \\
$\begin{array}{ll}\text { Imprensa da Universidade de Coimbra; Faculdade de Ciências e } \\
\text { Publicado por: }\end{array}$ \\
$\begin{array}{l}\text { Tecnologia da Universidade de Coimbra, Departamento de Engenharia } \\
\text { Mecânica }\end{array}$ \\
$\begin{array}{l}\text { URL } \\
\text { persistente: }\end{array}$ & URI:http://hdl.handle.net/10316.2/33317 \\
DOI:http://dx.doi.org/10.14195/978-972-8954-42-0_8 & 26-Apr-2023 08:19:36 \\
\hline
\end{tabular}

A navegação consulta e descarregamento dos títulos inseridos nas Bibliotecas Digitais UC Digitalis, UC Pombalina e UC Impactum, pressupõem a aceitação plena e sem reservas dos Termos e Condições de Uso destas Bibliotecas Digitais, disponíveis em https://digitalis.uc.pt/pt-pt/termos.

Conforme exposto nos referidos Termos e Condições de Uso, o descarregamento de títulos de acesso restrito requer uma licença válida de autorização devendo o utilizador aceder ao(s) documento(s) a partir de um endereço de IP da instituição detentora da supramencionada licença.

Ao utilizador é apenas permitido o descarregamento para uso pessoal, pelo que o emprego do(s) título(s) descarregado(s) para outro fim, designadamente comercial, carece de autorização do respetivo autor ou editor da obra.

Na medida em que todas as obras da UC Digitalis se encontram protegidas pelo Código do Direito de Autor e Direitos Conexos e demais legislação aplicável, toda a cópia, parcial ou total, deste documento, nos casos em que é legalmente admitida, deverá conter ou fazer-se acompanhar por este aviso.

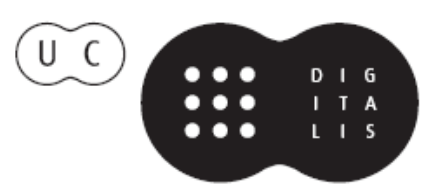




\title{
Life Cycle Cost Optimization
}

\section{through an Asset Management based on Risk Principles}

\author{
João Santos ${ }^{1}$; Hugo Barata ${ }^{2}$; Hélio Cordeiro ${ }^{3}$; Cristina Mendonça ${ }^{4}$; José Sobral ${ }^{5}$ \\ 1joaosantos8@hotmail.com; ${ }^{2}$ h.reibarata@gmail.com; ${ }^{3}$ heliodmcordeiro@gmail.com ; \\ ${ }^{4}$ mclvmendonca@gmail.com; ${ }^{5}$ jsobral@dem.isel.ipl.pt \\ 1,2,3,5 Mechanical Engineering Department, ISEL - Instituto Superior de Engenharia de Lisboa \\ Lisboa, Portugal \\ ${ }^{4}$ SOCIUS - Research Centre in Economic and Organizational Sociology, ISEG \\ Lisboa, Portugal \\ ${ }^{5}$ CENTEC - Center for Marine Technology and Engineering, IST - Instituto Superior Técnico \\ Lisboa, Portugal
}

\begin{abstract}
When someone talks about assets life cycle optimization, the objective is mainly related with the reduction of operational and maintenance costs. However, regarding the newly asset management concept based on PAS 55 and the recent ISO 55000 standards family, this optimization should take into account and consider other issues like the risk associated with those decisions. Risk can be identified for each potential failure mode using a simplified FMEA (Failure Modes and Effects Analysis) and ranked or included into categories upon a determined and assumed criteria. Based on the previous risk level the decision making process aims to identify which hard time maintenance activities can be delayed in time in order to reduce maintenance costs and thus optimize the asset life cycle cost. The present paper presents a case study of equipment installed on a war vessel (diesel generators) and tries to assess if some relative hard time maintenance can be delayed without compromising safety. The amount of money to keep risk under the acceptable limits is then compared with the earning value related to the delay of maintenance activities. This work is supported by effective data gathered along the years for this specific equipment, which permits to have a realistic approach of the proposed decision. The chosen system operates on a maritime environment, has its last overhaul on 2010 and has been operating worldwide since then.
\end{abstract}

Keywords - FMEA, diesel generator, cost, risk.

\section{INTRODUCTION}

One of the main concerns of engineers and technicians with responsibilities on asset management is to keep risk under acceptable limits and at the same time promote an optimised life cycle cost.

Usually the problem is to combine these two areas of conflict in a way to achieve the best compromise. Frequently there is some difficulty to identify the probability of occurrence of undesired events and the severity of such situations and thus calculate the risk associated to the potential failure modes, although the several methodologies and tools available to reach such objective.
In almost industrial fields maintenance activities follow the manufacturer instructions and recommendations and so hard time maintenance programmes are followed and accomplished. Sometimes the frequency established for those activities is not the appropriate considering the working conditions of the assets. The decision to modify maintenance intervals is not so simple and must be based on trusted and proven information.

In the Portuguese Navy this concept is also applied and mostly systems installed in war vessels fulfil the requirements of hard time maintenance (HTM). This complies with some activities of condition based maintenance (CBM) and sometimes the necessarily corrective maintenance.

This paper intends to analyse specific equipment that exists in a vessel and verify if some hard time maintenance activities can be delayed in time taking into account the maximum risk acceptable once it is critical equipment. The objective is to compare the amount of money saved with this decision with the cost to keep risk under a pre-defined level.

To accomplish this work a Failure Mode and Effects Analysis (FMEA) was applied, including some additional studies. The paper is structured in four sections. Section II refers the Failure Mode and Effects Analysis (FMEA) methodology, its characteristics, benefits and drawbacks and Section III presents diesel generators as the equipment under study describing the use of such equipment on a war vessel and on maritime environment. Section $\mathrm{V}$ corresponds to the development of the case study and section VI points out some conclusions and future works that can be done on the sequence of the present study.

\section{FAILURE Mode AND EFFECTS ANALYSIS (FMEA)}

A Failure Mode and Effect Analysis (FMEA) is an engineering technique used to define, identify and eliminate known and potential failures, problems, errors, design process and/or service. It is a systematic approach and a mental discipline that an engineer normally goes through in any manufacturing process [1]. A FMEA is a living document based on experience, past concerns and key performance 
indicators. Most of times FMEA is an inductive approach to support risk assessment studies.

This methodology was first proposed by NASA in the $1960 \mathrm{~s}$ in order to fulfil reliability requirements. From then, it has been extensively applied as a powerful technique for system safety and reliability analysis of products and processes [2].

Several studies applying FMEA can be observed in a huge variety of subjects, since automotive, aeronautical, military and nuclear, among others. For example, Arabian-Hoseynabadi [3] applies this methodology to study the reliability of a wind turbine system and compares the results to reliability field data from real wind turbines systems and their assemblies.

Medicine is also a potential field for the application of FMEA. Recently many papers and studies use this tool as a guide to identify failure modes in this area. Chiozza and Ponzetti [4] used a FMEA to identify medical errors in order to prevent and reduce them and thus improve patient safety. In other work [5] the FMEA was applied to intraoperative radiation therapy just to prevent accidental exposures to the patient.

Cicek and Celik [6] applied the method to prevent crankcase explosion failure on a ship engine. The impact of such event can be catastrophic with damage on ship structure or on the crew members.

Feili et al [7] made a risk analysis of geothermal power plants using the FMEA technique to identify and analyse common cause failures (CCF) that could affect this type of installation.

In other cases FMEA is used in early stages of design in order to systematically improve processes and reduce project cost [2]. Usually, in a FMEA there are three measures under consideration: the probability of occurrence $(\mathrm{O})$, the severity of the consequences $(\mathrm{S})$ and the detectability of the failure before it occurs (D). The product of these three factors gives a parameter called risk priority number (RPN).

$$
R P N=(O) \times(S) \times(D)
$$

The team should be focused on failure modes with higher RPN once this means higher risk. So, using a risk matrix, RPN is used to identify acceptable and non-acceptable failure modes, providing a hierarchy of failures in accordance to the RPN achieved.

A criticism of FMEA is usually related to the possibility of failure modes with lower RPN could have some factors (like severity) with high values and sometimes it is not observed when someone only looks to the RPN value. After determining RPN some recommendations or corrective actions should be performed with the objective:

- To reduce or eliminate the probability of occurrence of the causes;

- To reduce the severity of the effects of the consequences;
- To increase the detectability of the failure before its occurrence.

When the analysis of failure modes is developed on a system, people can go into a desired level of detail just to identify potential failure modes before they occur and may cause undesirable events. So, the risk of failure is minimised by proposing design or operational changes.

A FMEA is a team work including experienced engineers and people familiar with project as well as experts who have a deep understanding of the product or process. The expertise team can vary according to the scope and complexity of the focused problem.

The FMEA process covers the following steps:

- Analysis of the process, product or system;

- Description of each function;

- List of the identified potential failures (functional failures);

- Evaluation of their frequency, severity and detection technique;

- Global evaluation (includes RPN analysis);

- Identification of corrective actions or recommendations

\section{DIESEL GENERATORS IN A VESSEL}

The physical assets analysed in the present work are diesel generators consisting in diesel engines coupled to alternators. These systems are installed in a vessel and mainly work in a maritime environment. This type of generator is prepared to work in a maritime condition, due to utilization of seawater for refrigeration purposes.

At the present study, it was considered the example of diesel generators from a modern Portuguese Navy vessel (frigate). The frigate platform has four diesel generators, each one with $655 \mathrm{~kW}$, in a total power of $2620 \mathrm{~kW}$. The generators provide $440 \mathrm{~V} / 60 \mathrm{~Hz}$ to two main switchboards that distributes energy for the entire platform. The vessel in a sailing situation requires two generators in permanent function and, when alongside, only one is required. Figure 1 shows a view of the diesel engine analysed in the present work.

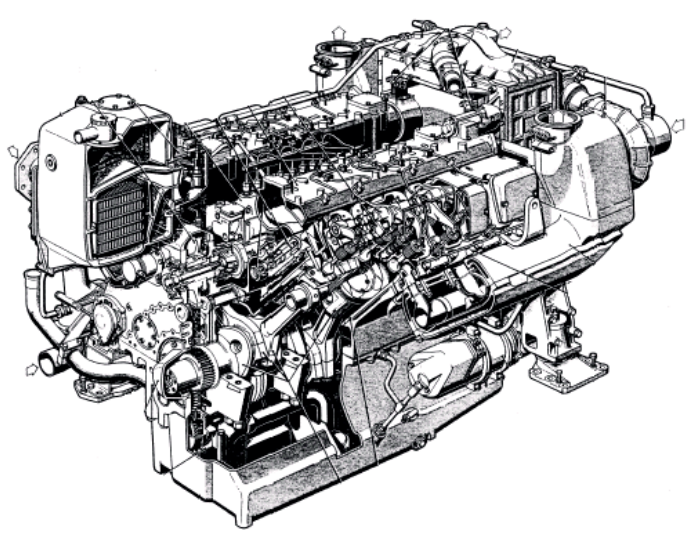

Figure 1. Diesel Generator MTU 8V 396 TB53 
The studied equipment is a MTU V8 Diesel generator, adapted to maritime applications. These generators are in use since 1991 and have been maintained according to the MTU maintenance program. The MTU maintenance program foresees the follow maintenance activities [8]:

- W1: This is a daily maintenance task which previews the verification of well-functioning parameters.

- W2, W3 and W4: These maintenance tasks are made by the operators during the generator stoppage period. The tasks are done in the function local and with the follow periodicity:

\section{- W2: 250 hours or 6 months \\ - W3: 1000 hours or 1 year \\ - W4: 2000 hours or 2 years}

- W5: This maintenance task is a partial overhaul. It requires the partial dismantling of the engine. This maintenance has a periodicity of 6000 hours or 6 years.

- W6: This maintenance task is an overhaul to the engine. It requires the entire dismantling of the engine and has a periodicity of 24000 hours or 12 years.

In the scope of this paper, the engine was decomposed in its subsystems in a way to perform a FMEA.

The diesel generator was decomposed in: (1) Cylinder Head; (2) Engine block; (3) Sump; (4) Alternator; (5) Rotor; (6) Stator; (7) Shaft; (8) Bearing shaft; (9) Ventilator; (10) Auxiliary equipment; (11) Cooled exhaust manifold; (12) Charge air cooler; (13) Housing cooler; (14) Alternator cooler; (15) Coupling; (16) Regulator and speed limiter; (17) Fuel feed pump; (18) Injection pump; (19) Lubrication oil pump; (20)
Coupled refrigeration water pump; (21) Coupled seawater pump; (22) Diesel engine turbocharger; (23) Pre-refrigeration water heater; (23.1) Heater; (23.2) Circulation water pump [9].

In accordance to the data available concerning the failures occurred in the several subsystems there were selected three of them to build the FMEA and serve as an example. The chosen systems were:

- The lubrication system (oil);

- The refrigeration system (water)

- The fuel oil system.

These subsystems were chosen because almost the failures registered on generators occurred on them.

\section{DEVELOPMENT OF A CASE STUDY}

The purpose of the present study is to quantify the risk associated to the rescheduling of the overhaul (W5), how to keep it under acceptable limits and how it costs. It is took into account all historical data from this diesel generator.

The first step of the present case study was to identify all the subsystems inside each pre-selected system. Then, for each of these subsystems were defined the inherent functions and all possible failure modes, assuming a failure mode when the function is not accomplished.

After that, it was studied the possible causes associated to each failure and the link to the specific maintenance programme (W's) that should be performed on the respective subsystem.

For the allocation of probability of occurrence $(\mathrm{O})$, severity (S) and detectability (D) were used matrices based on MILSTD 1629A [10]. The referred matrices were adapted to the present study. These matrices are shown on Table I, II and III, respectively.

TABLE I. PROBABILITY OF OCCURRENCE MATRIX

\begin{tabular}{|c|c|c|}
\hline \multirow{2}{*}{$\begin{array}{c}\text { Probability } \\
\text { level }\end{array}$} & \multicolumn{2}{|l|}{ Occurrence Matrix } \\
\hline & Description & Classification \\
\hline Frequent & $\begin{array}{l}\text { A high probability of occurrence during the item operation time interval. High probability } \\
\text { may be defined as a single failure mode. Probability greater than } 0.20 \text { of the overall } \\
\text { probability of failure during the item operating time interval. }\end{array}$ & 5 \\
\hline $\begin{array}{l}\text { Reasonably } \\
\text { Probable }\end{array}$ & $\begin{array}{l}\text { A moderate probability of occurrence during the item operating time interval. Probable } \\
\text { may be defined as a single failure mode probability of occurrence which is more than } 0.10 \\
\text { but less than } 0.20 \text { of the overall probability of failure during the item operating time. }\end{array}$ & 4 \\
\hline Occasional & $\begin{array}{l}\text { An occasional probability of occurrence during item operating time interval. May be } \\
\text { defined as a single failure mode probability of occurrence which is more than } 0.01 \text { but less } \\
\text { than } 0.10 \text { of the overall probability of failure during the item operating time. }\end{array}$ & 3 \\
\hline Remote & $\begin{array}{l}\text { An unlikely probability of occurrence during item operating time interval. May be defined } \\
\text { as a single failure mode probability of occurrence which is more than } 0.001 \text { but less than } \\
0.01 \text { of the overall probability of failure during the item operating time. }\end{array}$ & 2 \\
\hline $\begin{array}{l}\text { Extremely } \\
\text { unlikely }\end{array}$ & $\begin{array}{l}\text { A failure whose probability of occurrence is essentially zero during item operating time } \\
\text { interval. May be defined as a single failure mode probability of occurrence which is less } \\
\text { than } 0.001 \text { of the overall probability of failure during the item operating time. }\end{array}$ & 1 \\
\hline
\end{tabular}


TABLE II. SEVERITY MATRIX

\begin{tabular}{|c|c|c|c|c|c|}
\hline \multirow[b]{2}{*}{ Category } & \multicolumn{5}{|c|}{ Severity Matrix } \\
\hline & Causes & Safety & $\begin{array}{c}\text { Unavailability } \\
\text { period }\end{array}$ & Power loss & Classification \\
\hline Catastrophic & $\begin{array}{l}\text { A failure which may cause death. Loss } \\
\text { of power for more than } 30 \mathrm{~min} \text {. Power } \\
\text { output for less than } 60 \% \text {. }\end{array}$ & Death & $>30 \mathrm{~min}$ & $<60 \%$ & 4 \\
\hline Critical & $\begin{array}{l}\text { A failure which may cause severe } \\
\text { injury. Loss of power until } 30 \mathrm{~min} \text {. } \\
\text { Power output between } 60 \text { to } 80 \% \text {. }\end{array}$ & $\begin{array}{l}\text { Serious } \\
\text { injuries }\end{array}$ & $\leq 30 \mathrm{~min}$ & $60 \%<\mathrm{P} \leq 80 \%$ & 3 \\
\hline Marginal & $\begin{array}{l}\text { A failure which may cause minor injury. } \\
\text { Power output between } 80 \% \text { and } 100 \% \text {. }\end{array}$ & $\begin{array}{l}\text { Minor } \\
\text { injuries }\end{array}$ & 0 & $80 \%<\mathrm{P} \leq 100 \%$ & 2 \\
\hline Minor & $\begin{array}{l}\text { A failure not serious enough to cause } \\
\text { injury. System damage, but which will } \\
\text { result in unscheduled maintenance or } \\
\text { repair. }\end{array}$ & $\begin{array}{l}\text { No } \\
\text { injuries }\end{array}$ & - & - & 1 \\
\hline
\end{tabular}

TABLE III. DETECTABILITY MATRIX

\begin{tabular}{|l|l|c|}
\hline \multicolumn{1}{|c|}{ Detectability Grade } & \multicolumn{1}{c|}{ Detectability Matrix } & Description \\
\cline { 2 - 4 } Easily detectable & Automatic detection of the fault before occurs. & 1 \\
\hline Moderately detectable & Fault detection through inspection, before the effects are produced. & 2 \\
\hline Hardly detectable & Failure detection before their effects are felt through advanced diagnostics. & 3 \\
\hline Unable to detect & Failure cannot be detected before the effects are produced & 4 \\
\hline
\end{tabular}

Based on the classification used to categorize each failure mode a risk priority number (RPN) was achieved. This number represents the risk associated to each identified potential failure.

The probabilities of occurrence were determined upon the available historic data referred to the last three years. Based on that, it was analysed the number of occurrences registered and the inherent value for probability.

The severity was analysed taking into account the impact on the health of the crew, the system unavailability period and the generator power loss.
The detectability grade measure how difficult is the identification of the failure before it happens.

The risk acceptance criteria are based on the following rule:

- Acceptable-RPN from 1 to 10;

- Acceptable with remarks - RPN from 11 to 20;

- Unacceptable - RPN from 21 to 80.

So, after determining the RPN for each failure mode the result shows that three of them were in the "unacceptable" zone, as presented in Table IV.

TABLE IV. INITIAL UNACCEPTABLE RPN's

\begin{tabular}{|c|l|l|l|l|l|l|c|c|}
\hline \multirow{2}{*}{ FM \# } & \multicolumn{1}{|c|}{ System } & \multicolumn{1}{|c|}{ Sub system } & \multicolumn{1}{c|}{ Function } & \multicolumn{1}{c|}{ Failure Mode } & $\boldsymbol{O}$ & $\boldsymbol{S}$ & $\boldsymbol{D}$ & $\boldsymbol{R} \boldsymbol{P} \boldsymbol{N}$ \\
\cline { 2 - 9 } & $\begin{array}{l}\text { Lubrication oil } \\
\text { system }\end{array}$ & $\begin{array}{l}\text { Lubrication oil } \\
\text { cooler }\end{array}$ & $\begin{array}{l}\text { Keep the oil at the right } \\
\text { temperature conditions }\end{array}$ & The oil is not cooled & 5 & 3 & 2 & 30 \\
\hline B & Fuel system & $\begin{array}{l}\text { Diesel injection } \\
\text { pump }\end{array}$ & $\begin{array}{l}\text { Compresses the fuel with } \\
\text { the right sequence and } \\
\text { injection pressure }\end{array}$ & $\begin{array}{l}\text { There are no fuel } \\
\text { compression }\end{array}$ & 2 & 2 & 4 & 32 \\
\hline C & Cooling system & $\begin{array}{l}\text { Saltwater circuit } \\
\text { accessories }\end{array}$ & $\begin{array}{l}\text { Ensure the water flow rate, } \\
\text { pressure and containment } \\
\text { along the circuit }\end{array}$ & $\begin{array}{l}\text { Saltwater circulation } \\
\text { interruption }\end{array}$ & 2 & 3 & 4 & 24 \\
\hline
\end{tabular}

For these failure modes some recommendations were suggested just to reduce the RPN at least to the "acceptable with remarks" range of results. These recommendations are related to some modifications in the monitoring process that may cause some changes in the classifications of $\mathrm{O}, \mathrm{S}$ and $\mathrm{D}$ :
FM \#A - Control pressure changes along the circuit or evaluate the thermal gradient provided by the cooler. Clean or repair the oil cooler during downtime. With this, pressure problems are detected, reducing the probability of occurrence and increasing its detectability. 
FM \#B - Condition monitoring using vibration analysis, enhancing detectability.

FM \#C - Control pressure changes in the circuit and draw a graphic which represents the pressure loss trend, enhancing detectability.

The implementing costs are:

- $\mathrm{FM} \# \mathrm{~A}=400$ euros
- $\quad \mathrm{FM} \# \mathrm{~B}=150$ euros

- $\mathrm{FM} \# \mathrm{C}=$ without cost (only internal human resources are used. Cost not considered)

Now, assuming the successful implementation of recommendations, all RPN related to the analysed failure modes (now called $\mathrm{RPN}^{1}$ ) are positioned in an acceptable level as shown on Table $\mathrm{V}$.

TABLE V. RPN ${ }^{1}$ VALUES AFTER IMPLEMENTING RECOMMENDATIONS

\begin{tabular}{|c|c|c|c|c|c|c|}
\hline \multirow{2}{*}{ FM \# } & \multicolumn{7}{|c|}{ FMEA - Diesel Generator } \\
\cline { 2 - 7 } & $\boldsymbol{R P N}$ & $\boldsymbol{O}^{\boldsymbol{I}}$ & $\boldsymbol{S}^{\boldsymbol{I}}$ & $\boldsymbol{D}^{\boldsymbol{I}}$ & $\boldsymbol{R P}^{\boldsymbol{I}}$ & Modification Cost \\
\hline A & 30 & $\mathbf{4}$ & 3 & $\mathbf{1}$ & 12 & 400 euros \\
\hline B & 32 & 2 & 4 & $\mathbf{2}$ & 16 & 150 euros \\
\hline C & 24 & 2 & 3 & $\mathbf{2}$ & 12 & 0 euros \\
\hline \multicolumn{8}{|c|}{ Total Cost } \\
\hline
\end{tabular}

The next step was taking the decision to delay one year the W5 maintenance programme and analyse the impact of such decision on risk (RPN).

In the absence of coherent information about such scenario it was assumed that the announced delay of W5 maintenance activities will produce an increase of one level on the probability of occurrence of each failure mode related with W5 programme.

Based on this believed assumption new RPN's were determined (now called $\mathrm{RPN}^{2}$ ). Five new situations of unacceptable $\mathrm{RPN}^{2}$ values were achieved, as presented in Table VI.

TABLE VI. NEW RPN VALUES AFTER ONE YEAR OF DELAY (W5)

\begin{tabular}{|c|c|c|c|c|c|c|c|c|}
\hline \multirow{2}{*}{ FM \# } & \multicolumn{8}{|c|}{ FMEA - Diesel Generator } \\
\hline & System & Sub system & Function & Failure Mode & $\mathrm{O}^{2}$ & $S^{I}$ & $D^{1}$ & $R P N^{2}$ \\
\hline B & Fuel system & $\begin{array}{l}\text { Diesel injection } \\
\text { pump }\end{array}$ & $\begin{array}{l}\text { Compresses the fuel with the right } \\
\text { sequence and injection pressure }\end{array}$ & $\begin{array}{l}\text { There are no fuel } \\
\text { compression }\end{array}$ & 3 & 4 & 2 & 24 \\
\hline $\mathrm{D}$ & Fuel system & $\begin{array}{l}\text { Fuel system } \\
\text { accessories }\end{array}$ & $\begin{array}{l}\text { Ensure correct fuel flow along the } \\
\text { circuit, pressure and correct containment }\end{array}$ & Disrupted circuit & 2 & 3 & 4 & 24 \\
\hline $\mathrm{E}$ & Fuel system & Leakage tank & Hold fuel leaks & Tank rupture & 2 & 3 & 4 & 24 \\
\hline $\mathrm{F}$ & Fuel system & Fuel pump & $\begin{array}{l}\text { Pressurizes the fuel in the service tank } \\
\text { and sends it in the injection pump }\end{array}$ & $\begin{array}{l}\text { Does not } \\
\text { compress fuel }\end{array}$ & 2 & 4 & 3 & 24 \\
\hline G & $\begin{array}{l}\text { Cooling } \\
\text { system }\end{array}$ & Refrigeration & $\begin{array}{l}\text { Accessories of refrigeration water } \\
\text { circuit }\end{array}$ & $\begin{array}{l}\text { There is no } \\
\text { refrigeration water } \\
\text { circulation }\end{array}$ & 2 & 3 & 4 & 24 \\
\hline
\end{tabular}

Once again were suggested some recommendations in a way to decrease unacceptable RPN situations (again at least to the "acceptable with remarks" level).

FM \#B - Condition monitoring using vibration analysis, enhancing detectability.

FM \#D - Control pressure changes in the circuit and draw a graphic which represents the pressure loss trend, enhancing detectability.

FM \#E - Periodic inspections of tank thickness. This action increases detectability.

FM \#F - Condition monitoring using vibration analysis, enhancing detectability.

FM \#G - Control pressure changes along the circuit using pressure sensors strategically mounted in a few points of the circuit. Than anticipate a reactive action before the effects are produced. Enhance the detectability.
This set of measures implies the following costs:

- $\quad \mathrm{FM} \# \mathrm{~B}=150$ euros

- $\mathrm{FM} \# \mathrm{D}=$ without cost (only internal human resources are used. Cost not considered)

- $\quad \mathrm{FM} \# \mathrm{E}=150$ euros

- $\quad \mathrm{FM} \# \mathrm{~F}=150$ euros

- $\quad \mathrm{FM} \# \mathrm{G}=400$ euros

If the implementation of these proposals is considered, the impact on $\mathrm{RPN}^{2}$ can be assessed and new values for this indicator achieved (called final RPN or $\mathrm{RPN}^{3}$ ) resulting on the Table VII. 
TABLE VII. FINAL RPN $\left(\mathrm{RPN}^{3}\right)$

\begin{tabular}{|c|c|c|c|c|c|c|}
\hline \multirow{2}{*}{ FM \# } & \multicolumn{7}{|c|}{ FMEA - Diesel Generator } \\
\cline { 2 - 7 } & $\boldsymbol{R} \boldsymbol{P} \boldsymbol{N}^{2}$ & $\boldsymbol{O}^{3}$ & $\boldsymbol{S}^{3}$ & $\boldsymbol{D}^{3}$ & $\boldsymbol{R P N}^{3}$ & Modification Cost \\
\hline B & 24 & $\mathbf{2}$ & 4 & 2 & 16 & 150 euros \\
\hline D & 24 & 2 & 3 & $\mathbf{3}$ & 18 & 0 euros \\
\hline E & 24 & 2 & 3 & $\mathbf{3}$ & 18 & 150 euros \\
\hline F & 24 & 2 & 4 & $\mathbf{2}$ & 16 & 150 euros \\
\hline G & 24 & 2 & 3 & $\mathbf{3}$ & 18 & 400 euros \\
\hline \multicolumn{7}{|c|}{ Total Cost } \\
\hline
\end{tabular}

As it can be seen, the total cost related to the implementation of the measures is about 1.400 euros. However for the present study only 850 euros will be considered once the cost to reduce RPN to RPN ${ }^{1}$ is always necessary in the present moment if one wants to keep risk under the acceptable limits.

This value is assumed to be spent in every sixth years after the partial overhaul corresponding to W5 (revised).

Now, is time to determine the profit of delaying the W5 maintenance programming for one year, changing from 6 to 7 years the scheduled activities.

According to the registered historic values concerning the cost of a W5 task, including an outsourcing contract, spare parts and material necessary to perform it, results in a global value of approximately 71.000 euros each 6 years.

For a more realistic observation about the impact of this simple (but complex) decision it was analysed the behaviour of cumulative costs along the years in a temporal distance of 30 years, as shown in Figure 2.

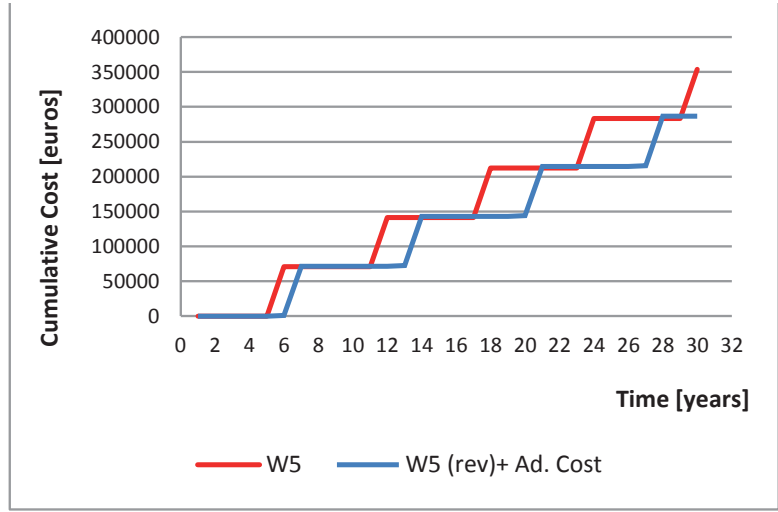

Figure 2. Comparison of the evolution of cumulative costs

As it can be seen costs vary on time. For the actual W5 partial overhaul (red line) cost increase earlier than for the proposed W5 (W5 revised) added the cost related to the implementation of risk reduction measures (blue line). With the passing time this gap has more significance.

\section{CONCLUSIONS AND FUTURE WORKS}

This work deals with maintenance and tries to demonstrate the relationship between cost and risk. In the present study a FMEA was applied to a specific equipment (diesel generator) installed in a war vessel just to identify its failure modes and determine the risk level associated. Based on historic failures some subsystems were identified and selected for the present case study.

Then it was proposed a change on the frequency of a hard time maintenance programme, delaying the inherent activities for a year. The amount of money earned with this decision is then compared with the estimated cost for keeping risk under acceptable limits referred in a pre-defined risk matrix.

Based on the present study it was shown that it is worth to make that decision, resulting on a profit once the cumulative cost appear in a later moment. All of this is achieved without compromising safety.

As future works, one may say that is necessary a validation of the values concerning the proposed measures in the present study as well as a more accurate study on the probabilistic data related to the failures registered along the years. It is also necessary to extend the FMEA to other subsystems covering the entire parts of the diesel generator. Later, it is also necessary to observe the impact of such decision as a whole, once a vessel has four diesel generators. This step is important for safety and operational purposes.

The present work shows in a clearly way that is possible to manage and optimise the life cycle cost of an asset taking into account risk principles.

\section{ACKNOWLEDGMENT}

The authors want to give a special acknowledgment to the Propulsion and Energy Department of NRP Álvares Cabral (Portuguese Navy) for providing technical information and historic maintenance data for the present case study. 


\section{REFERENCES}

[1] Ahire, C. and Relkar, A., "Correlating Failure Mode Effect Analysis (FMEA) \& Overall Equipment Effectiveness (OEE)", Procedia Engineering, vol. 38, pp. 3482-3486, 2012.

[2] Bahrami, M., Bazzaz, D. and Sajjadi, S., "Innovation and Improvements in Project Implementation and Management; Using FMEA Technique", Procedia Social and Behavioral Sciences, vol. 41, pp. 418-425, 2012.

[3] Arabian-Hoseynabadi, H., Oraee, H. and Tavner, P., "Failure Modes and Effects Analysis (FMEA) for wind turbines", Electrical Power and Energy Systems, vol. 32, pp. 817-824, 2010.

[4] Ciozza, M. and Ponzetti, C., "FMEA: A model for reducing medical errors", Clinica Chimica Acta, vol. 404, pp. 75-78, 2009.

[5] Ciocca, M., Cantone, M., Veronese, I., Cattani, F., Pedroli, G., Molinelli, S., Vitolo, V. and Orecchia, R., "Application of failure mode and effects analysis to intraoperative radiation therapy using mobile electron linear accelerators, International Journal Radiation Oncology Biol. Phys., vol. 82, pp. 305-311, 2012.

[6] Cicek, K. and Cleik, M., "Application of failure modes and effects analysis to main engine crankwise explosion failure on-board ship", Safety Science, vol. 51, pp. 6-10, 2013.

[7] Feili, H., Akar, N., Lotfizadeh, H., Bairampour, M. and Nasiri, S., "Risk analysis of geothermal power plants using Failure Modes and Effects Analysis (FMEA) technique", Energy Conversion and Management, vol. 72, pp. 69-76, 2013.

[8] MTU “Diesel Engine V 396 T.3 - Maintenance Manual”, Germany 1995

[9] MTU "Diesel Engine 8V 396 TB 53 - Description and Operation Manual", Germany 1989.

[10] DoD, "MIL-STD 1629 A - Procedures for Performing a Failure Mode Effects and Criticality Analysis - Revision A“, Department of Defense of USA, 1980 